Nina Mojsova Kjoseva ${ }^{1}$

Martin Noveski ${ }^{2}$

\title{
GOVERNMENT'S EXCESSIVE SPENDING AND PRIVATE SECTOR'S ACCESS TO BANK CREDIT: EVIDENCE FROM THE REPUBLIC OF NORTH MACEDONIA
}

\begin{abstract}
Due to the crucial role of credit in the economic activity of a country, there is a growing empirical literature examining the determinants of domestic credit to the private sector, which may be demand-side or supply-side factors. It is commonly held that excessive domestic debt reduces private sector credit, raise bank lending rates, and shrink output as the Government competes with the private sector for private savings. For this reason, the aim of this paper is to determine whether persistent budget deficit in the Republic of North Macedonia negatively affects the private sector's access to bank credit, and hence slowing down the economic activity.

The analysis considers both, short-run and long-run relationship between domestic credit to private sector provided by banks and budget balance in North Macedonia, as endogenous variables, but also it takes into account the influence of several other exogenous factors. The methodological approach is consisted of visual inspection of the data, correlation analysis, co-integration and causality tests, as well as estimation of the impulse response function and variance decomposition. Based on the estimated VECM model, the results show statistically significant long-run relationship between the endogenous variables, and no short-run causality in any direction.
\end{abstract}

Key words: Budget balance, domestic credit to private sector; VECM model, co-integration, causality.

JEL: E44; O16; C320

1 MSc., Head of Reporting Department, Finance Division, Sparkasse Bank, AD Skopje, Republic of North Macedonia ( $\mathrm{PhD}$ candidate, Krakow University of Economics, Poland)

2 MSc., Senior Associate, Budget and Funds Department, Ministry of Finance, Republic of North Macedonia 


\section{INTRODUCTION}

Finance is a vital ingredient of economic growth, but there can be too much of it. Over the past 50 years, credit by banks and other institutions to households and businesses has grown three times as fast as economic activity. At these levels, further expansion is likely to slow long-term growth and raise inequality (OECD, 2015). However, the proportion of credit going to households (as opposed to businesses) in overall credit has risen considerably over past decades. This trend matters because credit is a stronger drag on growth when it goes to households rather than businesses. Private investment in developing countries critically depends on the availability of bank credit, especially given the fact that the capital market is not well developed. Thus, crowding out of bank credit may have significant adverse effects on private investment and consequently on economic growth in developing countries (Emran and Farazi, 2009)

Due to the crucial role of credit in the economic activity of a country, there is a growing empirical literature examining the determinants of domestic credit to the private sector, which may be demand-side or supply-side factors. It is commonly held that excessive domestic debt reduces private sector credit, raise bank lending rates, and shrink output as the Government competes with the private sector for private savings.

In this respect, subject of analysis is the relationship between access of private sector to bank credit and excessive government spending in North Macedonia, both in short-run and long-run.

\section{Review of previous research}

The relationship between budget deficits and macroeconomic variables such as growth, interest rates, and private investment, among others, represents one of the most widely debated topics among economists and policymakers. Theoretical and empirical literature are not conclusive about the nature of some of the abovementioned relationships, but generally the method of financing government expenditures and the type of expenditure could play a significant role in shaping the relationship between the budget deficit on one side and investment and growth on the other side. In general, the key outcomes from the literature indicate that both the method of financing the deficit and the components of government expenditures could have different effects on private investment and growth.

There is a vast amount of literature analyzing determinants of credit growth to the private sector. In their paper, Shijaku and Kalluci (2013) studied the determinants of bank credit to the private sector in the case of Albania using the Johansen VECM 
methodology. The study identified a co-integrating relationship linking real bank credit to the private sector, real GDP, net wages, banking and financial developments, financial liberalization indicators, exchange rate, non-performing loans and interest rates. In addition, Ademi (2016), in his paper, aims to explain the dynamics of bank credit to private sector across countries through an analysis of its potential financial determinants. He found out that the most significant financial factor and influential on the credit towards the private sector are the deposits as \% of GDP. However, the factors that are important and that are negatively correlated with the loan are, the real interest rate which with its rise causes the contraction of the credit, and in return increase of the banking concentration, where with the growth of the percentage level of concentration the credit level gets low, too. Moreover, Ivanovic (2017), in her paper, focuses on identification and estimation of determinants of credit growth in Montenegro, exploring both demand and supply side factors, and particularly paying attention to supply factors. Her findings confirm that positive economic developments and an increase in banks' deposit potential lead to higher credit growth. Furthermore, her findings emphasize that the banking system soundness is decisive for promoting further bank's lending activities. In addition, her findings suggest that once the financial crisis took a place, the determinants of credit growth slightly change. Namely, in the pre-crisis period, the contribution of the GDP growth rate, deposit growth, solvency ratio and banks` efficiency have positive significant influence on the credit growth. In contrary, in the post-crisis period the contribution of GDP and solvency ratio was not found to be significant.

In theory, domestic public debt can bring many benefits to the countries. It plays an important role for growth and raising funds for long-term development projects and supports financial systems in credit intermediation and during crisis periods. In contrast, excessive public debt can have long-term negative consequences. Because of the recent global financial and economic crises, recent government deficit and debt ratios skyrocketed in many countries and represent potential threat to financial stability, especially in the low interest rate environment. In their paper, Emran and Farazi (2009) provide estimates of the magnitude of the crowding out effect of government borrowing on private credit using a panel data set on 60 developing countries for 32 years. Their paper shows that there is a significant crowding out effect of government borrowing from the domestic banks on private credit. They found that when government borrowing increases by one dollar, it reduces credit to the private sector by about one dollar and forty cents. Private investment in developing countries critically depends on the availability of bank credit especially given that the capital market is not well developed. Thus, crowding out of bank credit may have significant adverse effects on private investment and consequently on economic growth in developing countries. Moreover, Janda and Kravtsov (2017) investigated the time varying effe- 
cts of domestic public debts on the financial development, private credit and banking performance in the countries of the Central Eastern Europe, Balkan and Baltics region. The econometric results suggest that the most significant determinant of private debt is the growing public debt over the short-midterm horizon. This might imply the crowding-out effect of public debt on private credit in the region. The growth of public debt positively impacts the banking sector efficiency only over the short-term period, while we observe only minor time effects in responses to changes in public debt on the financial stability indicators.

\section{Data and methodology}

Following similar econometric techniques as Shijaku and Kalluci (2013), but from a different perspective, the empirical relationship between excessive government spending and the access of private sector to bank credit in North Macedonia (shortrun and long-run) is analyzed using dynamic vector autoregressive (VAR) and vector error correction mechanism (VECM) models. The methodological approach basically comes down to determination and estimation of appropriate econometric model, upon which reliable analysis can be further conducted. It starts by visual inspection of the model variables, correlation analysis and unit root tests, in order to check their structural properties and order of integration. Further, it continues with co-integration and causality tests, as well as estimation of the impulse response function and variance decomposition.

Here, one should have in mind the importance of the identification process of the variables and their order of integration, since inappropriate use of non-stationary data might cause meaningless and misleading results (Wooldrige, 2013, p.644). In this regards, VAR model is considered more suitable for stationary data, whereas for non-stationary data VECM model can be used, but only if there exists long run relationship (co-integration) between endogenous variables (Vogelvang, 2005, p.265). Additionally, important aspect is the number of time lags included in the model as well, especially when the sample size is small. The optimal number of lags (p) is determined using available information criteria, based on estimated VAR model for endogenous variables in levels. If all endogenous variables are I(1), p-1 lags are used for further conduction of Johansen co-integration test and re-estimation of the model with VECM (Brooks, 2008, p.350).

In accordance with the objectives of this paper, indicators for government's excessive spending are public debt (DEBT) and budget balance (BALANCE), as two main fiscal targets, whereas for the access of private sector to bank credit, that would be the domestic credit to private sector provided by banks (DCPSB). Additionally, several other macroeconomic factors, such as macroeconomic growth, stability of 
prices and interest rates, and the level of economic activity in the country, represented through the GDP growth rate, inflation rate, real interest rates and employment, are also taken into account. These factors serve only for controlling purposes, thus are considered exogenous.

Sample period observed is $1996-2017^{3}$, whereas data sources are the Ministry of Finance of North Macedonia (MoF) ${ }^{4}$, National Bank of the Republic of North Macedonia (NBRNM) $)^{5}$ and the World Bank (WB) ${ }^{6}$. Table 1 in continuation shows the full list of variables used in the analysis, along with their order of integration.

Given that DEBT and DCPSB are I(2), instead of using their first differences (Granger and Newbold, 1974), endogenous variables in the models are their respective flow variables, BALANCE and CREDIT.

Table 1: Full list of variables included in the model

\begin{tabular}{|c|c|c|c|}
\hline Variable & Indicator & Source & $\begin{array}{c}\text { Order of } \\
\text { integration }\end{array}$ \\
\hline DEBT & Public debt (\% of GDP) & $\mathrm{MoF}$ & $\mathrm{I}(2)$ \\
\hline DCPSB & $\begin{array}{l}\text { Domestic credit to private sector provided by banks ( } \% \text { of } \\
\text { GDP) }\end{array}$ & WB & $\mathrm{I}(2)$ \\
\hline CREDIT & $\begin{array}{c}\text { Domestic credit to private sector by banks and savings } \\
\text { houses (annual rates of change in \%) }\end{array}$ & $\begin{array}{c}\text { MoF / } \\
\text { NBRNM }\end{array}$ & $\mathrm{I}(1)$ \\
\hline BALANCE & $\begin{array}{l}\text { Budget Balance (central government budget and funds, } \% \\
\text { of GDP) }\end{array}$ & NBRNM & $\mathrm{I}(1)$ \\
\hline GDPg & GDP growth (annual \%) & WB & $\mathrm{I}(0)$ \\
\hline INF_cpi & Inflation, consumer prices (annual \%) & WB & $\mathrm{I}(0)$ \\
\hline RIR & Real interest rate $(\%)$ & WB & $\mathrm{I}(1)$ \\
\hline EMP & $\begin{array}{c}\text { Employment to population ratio, } 15+, \text { total (\%) (modeled } \\
\text { ILO estimate) }\end{array}$ & WB & $\mathrm{I}(1)$ \\
\hline
\end{tabular}

\section{Empirical results}

In the past period, public debt and domestic credit to private sector provided by banks in North Macedonia have strongly emphasized linear relationship. Although the correlation coefficient for the whole period (2002-2017) is 0.08 , it is misleading, since for the first six years (2002-2008) it is -0.97 , whereas for the second (2008-2017) it goes in opposite direction, or 0.93. Namely, in the pre-crisis period of economic expansion, North Macedonia has not only successfully reduced the level of public debt from $43 \%$ in 2002 to lowest $23 \%$ in 2008 , but has also experienced

3 Except for the public debt (DEBT), for which there is official data available starting from 2002 onwards.

4 https://finance.gov.mk/mk/node/57

5 http://nbrm.mk/osnovni_ekonomski_pokazateli-en.nspx

6 https://data.worldbank.org/country/north-macedonia?view=chart 
high-speed growth of the private sector activity (DCPSB rises 1.5 times in the same period). However, after 2008, global financial and economic crisis has led to considerable increase of the public debt, reaching almost 49\% of GDP in 2016, whereas domestic credit to private sector continued to rise with far slower dynamics (Illustration 1).

Illustration 1. Relationship between public debt and domestic credit to private sector provided by banks in North Macedonia
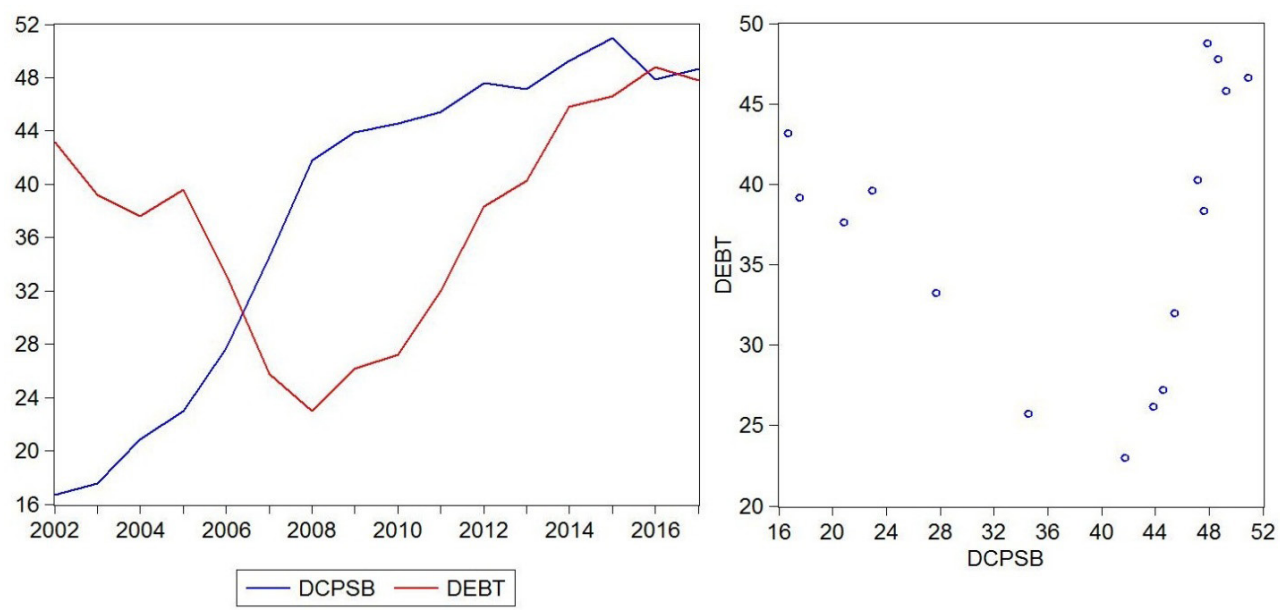

Source: Authors'illustration

Interesting observation here is the V-shaped scatter plot (picture right), revealing information that up until some point of around $42 \%$ DCPSB is increasing while at the same time public debt is decreasing, whereas above that threshold level, further increase of DCPSB is accompanied by far stronger increase of the public debt.

This two-fold relationship is also visible from Illustration 2, in which DCPSB and its corresponding flow variable CREDIT (annual rates of change) are put in correlation with the budget balance of the country (viewed as change of the public debt). Namely, for values of DCPSB above the threshold level there is negative budget balance (deficit), unlike balanced budget (around 0\% of GDP) when DCPSB is below that level. However, for low values of DCPSB (15-20\%), there is no correlation with the budget balance.

As for the annual rates of change of DCPSB, there is slight positive correlation with the budget balance (correlation coefficient is 0.62 ). 
Illustration 2. Correlation between BALNCE and DCPSB, and BALNCE and CREDIT
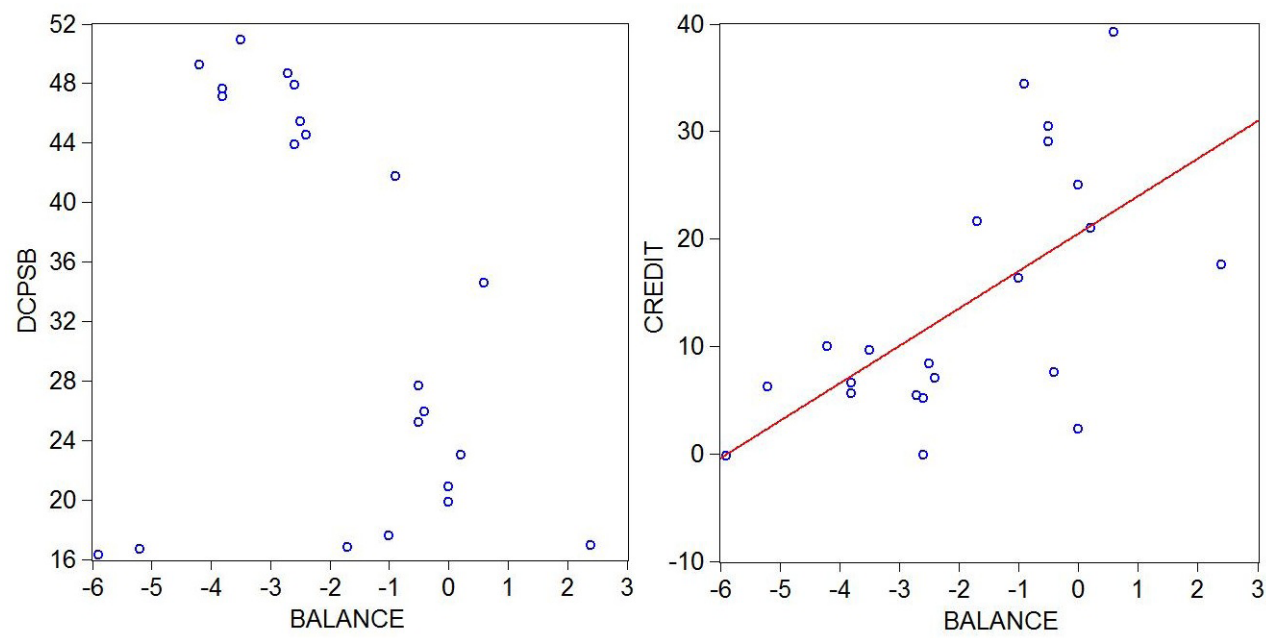

Source: Authors'illustration

However, since correlation analysis cannot reveal potential causal relationship between the variables of interest, further econometric methods are applied for better understanding of the mutual relationship.

Following previously elaborated methodology, Augmented Dickey-Fuller (ADF) unit root test, with automatic lag selection based on Schwarz information criterion for maximum 4 lags $(\alpha=0.05)$ is used to determine the order of integration of the variables (results shown in Table 1). In this regards, DEBT and DCPSB as stock variables are integrated of second order, I (2), whereas their respective flow variables BALANCE and CREDIT are I(1). Given that differentiating the series would make their meaning and interpretation much more complicated, the analysis continues using BALANCE and CREDIT as endogenous variables, instead of the differences of DEBT and DCPSB.

Regarding the length of the model, information criteria point out 2 optimal number of lags (p), whereby further application of Johansen co-integration test for $\mathrm{p}-1$ lags indicates 2 co-integrating equations. Based on these indications, VECM model with 1 lag is estimated, as most appropriate for further analysis. Estimated VECM model is consisted of 2 equations, with totally 16 estimated parameters (each equation is consisted of co-integrating equation, intercept, one lag of the two endogenous variables and four contemporary exogenous variables ${ }^{7}$ ), and 20 observations after adjustments.

7 For RIR and EMP variables first differences are used, given that they are both I(1). 
These estimated results are shown in Eq. (1) and Eq. (2).

$\mathrm{D}(\mathrm{CREDIT})=-0.85 *(\mathrm{CREDIT}(-1)-1.37 *$ BALANCE(-1)-16.28)-0.03*D(CREDIT(-1))

$+0.7 * D(B A L A N C E(-1))-12.69+4.44 * G D P G+1.32 * I N F \_C P I+1.33 * D(R I R)-4.61 * D(E M P)$

Eq. (1)

$\mathrm{D}(\mathrm{BALANCE})=0.01 *(\mathrm{CREDIT}(-1)-1.37 * \mathrm{BALANCE}(-1)-16.28)-0.03 * \mathrm{D}(\mathrm{CREDIT}(-1))$

$-0.2 *$ D(BALANCE(-1))-0.25+0.31*GDPG-0.32*INF_CPI-0.34*D(RIR)-1.06*D(EMP)

Diagnostic checks confirm that the estimated model satisfies the stability condition ${ }^{8}$, as well as all other assumptions related to the model residuals. Namely, there are no roots lying outside the unit circle, residuals are normally distributed, homoscedastic and not serially correlated.

Having in mind the subject of this paper, the analysis is narrowed down to the first equation. The adjusted R-squared coefficient of 0.747 for this equation shows that almost $75 \%$ of the variations in the dependent variable are explained by the variations in the selected set of independent variables, whereas F statistics of 9.03 indicates that it is statistically significant even at 0.001 significance level.

As for the estimated parameters, the co-integrating coefficient referring to the speed of adjustment is -0.85 and it is statistically significant, indicating fast convergence to the long-run equilibrium level (Vogelvang, 2005, p.269). Statistically significant are also the estimated parameters for the intercept and the exogenous variables, but not those of the lagged endogenous variables, indicating lack of short-run relationship. Granger causality test further supports this finding, by not revealing statistically significant relationship between the endogenous variables in any direction (p-values in Table 2 are greater than 0.05).

Table 2: VEC Granger Causality/Block Exogeneity Wald Tests

\begin{tabular}{|c|c|c|c|}
\hline \multicolumn{5}{|c|}{ Dependent variable: D(CREDIT) } \\
\hline Excluded & Chi-sq & df & Prob. \\
\hline D(BALANCE) & 1.097954 & 1 & 0.2947 \\
\hline \multicolumn{4}{|c|}{ Dependent variable: D(BALANCE) } \\
\hline Excluded & Chi-sq & df & Prob. \\
\hline D(CREDIT) & 0.505268 & 1 & 0.4772 \\
\hline
\end{tabular}

Source: Authors'calculation

Based on the estimated VECM model, impulse response function is estimated, in order to see the reaction of CREDIT to a shock of one standard deviation in BALANCE, as well as to a shock in its own time series. Namely, as can be seen from

8 The stability condition for VECM model, the number of unit roots should not exceed k-r, where k is number of endogenous variables and $\mathrm{r}$ is number of co-integrating equations. 
Illustration 3, the initial response of CREDIT to a shock in its own time series is relatively high in the first period, but fades away already in the next period. On the other hand, a shock in the budget balance causes long-term structural shift of almost 1.5 percentage points. Additionally, variance decomposition shows increasing influence of the variations in BALANCE to the variations of CREDIT, starting from around $15 \%$ share in the second period, to almost $40 \%$ in the tenth period.

Illustration 3. Illustration 3: Impulse responses and variance decomposition of CREDIT

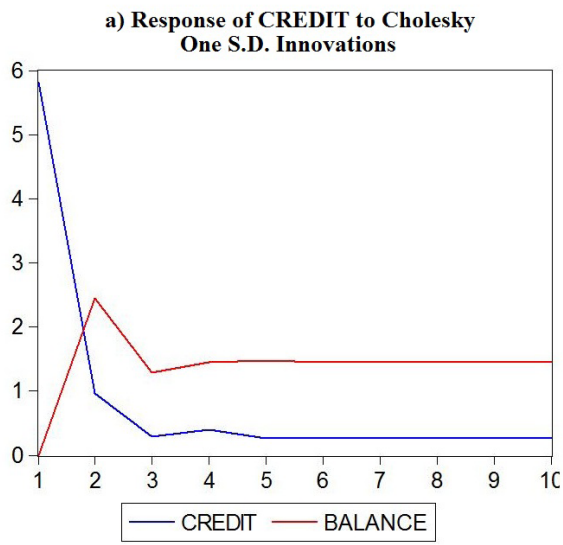

b) Variance Decomposition of CREDIT

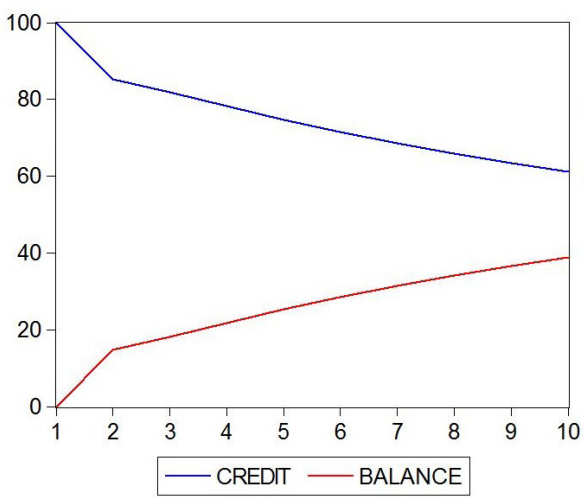

Source: Authors'illustration

\section{Limitations and further research}

Although conducted research provided meaningful and reliable results, there are some limitations worth pointing out. First, it is the short sample period (20 observations after adjustments) and the limitations coming out of it, primarily related to the number of estimated parameters in the model, as well as the number of lags. High number of model parameters would cause significant loss of degrees of freedom, jeopardizing thus the efficiency of the obtained results, as well as the overall model estimation. In this respect, increasing the number of lags in the model would also increase the number of parameters by multiple times, depending on the number of endogenous variables in the model.

Another limitation is the unavailability of important financial indicators (such as non-performing loans, capital adequacy ratio, etc.), especially for the pre-crisis period. As can be seen from Illustration 1, there are significant differences in the dynamics of the variables of interest in the pre-crisis and post-crisis period. Although in our analysis these factors are captured by the controlling exogenous variables, it would have been better to have wider possibilities. 
Finally, given that there is no short-term relationship between endogenous variables on one hand, whereas on the other exogenous variables are highly statistically significant, there might be other suitable econometric models.

Still, these limitations should not be considered as a restriction of the estimated model, but rather as an incentive for further research. Taking our findings as starting point for additional analysis would significantly improve the recommendations for the policy creators, not only in North Macedonia, but in other countries as well.

\section{CONCLUSIONS AND RECOMMENDATIONS}

Based on the conducted empirical analysis, it can be concluded that in North Macedonia almost perfect correlation exists between public debt and domestic credit to private sector provided by banks, negative in the pre-crisis and positive in the post-crisis period. When public debt decreases, DCPSB records high-speed growth, whereas when public debt increases, DCPSB continues to rise, but far slowly. In this respect, when the state budget is balanced DCPSB in North Macedonia varies between $20 \%$ and $40 \%$ of GDP, whilst its further increase after that threshold of around $40 \%$ is accompanied by an increase of the budget deficit and public debt.

As for the relationship between budget balance and the annual rates of change of DCPSB, another conclusion is that there exists moderate linear relationship, with correlation coefficient of 0.62 . Additionally, when taken into account factors like macroeconomic growth, stability of prices, interest rates, and the level of economic activity as exogenous, estimated VECM model with 1 lag shows statistically significant long-run relationship (co-integration), with high speed of adjustment towards the long-run equilibrium of -0.85 . However, no short-run causality has been found, in any direction.

In line with the above, a shock in the budget balance of one standard deviation would cause average 2.5 units initial impulse response in the annual rates of change of DCPSB, and 1.5 units shift in long-run, after the $3^{\text {rd }}$ period, everything else equal. Also, there is increasing share of the variations of budget balance in the variance of the annual rates of change of DCPSB over time, explaining up to $40 \%$ of these variations in long-run.

With respect to the above empirical findings for the case of North Macedonia, as well as the contemporary literature in this area, one should beware of the potential risks of high indebtedness (both public and private). More importantly, the long-run convergence between government's excessive spending and access of private sector to bank credit should be important information for decision makers and policy creators in the country, especially when imposing targets on these indicators. 


\section{REFERENCES}

1. Ademi, R. (2016). "Financial determinants of credit to the private sector". The Macrotheme Review 5 (1)

2. Brooks, C. 2008. Introductory econometrics for finance, $2^{\text {nd }}$ edition, Cambridge University Press, New York

3. Emran, S.M., Farazi, S. (2009). "Lazy Banks? Government Borrowing and Private Credit in Developing Countries". Available at: https://papers.ssrn.com/ sol3/papers.cfm?abstract_id $=1418145$

4. Granger, C.W.J., Newbold, P. (1974). "Spurious regression in econometrics", Journal of Econometrics, 2, pp.111-120.

5. Ivanovic, M. (2017). "Determinants of Credit Growth: The Case of Montenegro". Journal of Central Banking Theory and Practice, 2016, 2, pp. 101-118

6. Janda, K., Kravtsov, O. (2017). "Time-varying Effects of Public Debt on the Financial and Banking Development in the Central and Eastern Europe", MPRA Paper No. 77325

7. OECD (2015). "How to restore a healthy financial sector that supports long-lasting, inclusive growth?”. OECD Economics Department Policy Notes, No. 27

8. Shijaku, G., Kalluci, I (2013). "Determinants of bank credit to the private sector: The case of Albania". Working Paper No. 09 (48), Bank of Albania

9. Vogelvang, B. 2005. Econometrics, theory and application, with e-views, Pearson Education Limited, England

10. Wooldrige, J.M. 2013. Introductory econometrics, a modern approach, $5^{\text {th }}$ edition, South-Western Cengage Learning, USA

\section{PREKOMJERNA POTROŠNJA VLADE I PRISTUP PRIVATNOG SEKTORA BANKARSKOM KREDITIRANJU: EVIDENCIJA REPUBLIKE SJEVERNE MAKEDONIJE}

\section{SAŽETAK}

Zbog ključne uloge kreditiranja u ekonomskoj aktivnosti neke zemlje istovremeno raste znatiželja istraživača $i$ empirijske literature u kojoj se razmatraju determinante domaćih kredita privatnom sektoru, odnosno faktori koji mogu uticati na strani potražnje ili ponude. Uobičajeno se smatra da prekomjerni domaći dug smanjuje kre- 


\section{UNIVERSITY OF ZENICA FACULTY OF ECONOMICS}

ditiranje privatnog sektora, povećava kamatne stope banaka, i smanjuje proizvodnju jer se Vlada natječe sa privatnim sektorom za privatnu štednju. Stoga, cilj ovog rada je da se utvrdi da li je trajni proračunski deficit u Republici Sjevernoj Makedoniji negativno utjecao na pristup privatnog sektora bankovnim kreditima, a time i na usporavanje privredne aktivnosti. Analiza razmatra kratkoročne i dugoročne odnose između domaćih kredita privatnom sektoru koje osiguravaju banke i proračunske bilance u Sjevernoj Makedoniji kao endogene varijable, ali također uzima u obzir utjecaj nekoliko drugih egzogenih faktora. Metodološki pristup obuhvaća vizuelni pregled podataka, korelacijsku analizu, kointegraciju i testove uzročnosti, kao i procjenu funkcije impulsnog odziva i dekompozicije varijance. Na temelju procijenjenog VECM modela, rezultati pokazuju statistički značajan dugoročni odnos između endogenih varijabli, a ne kratkoročnu uzročnost u bilo kojem smjeru.

Ključne riječi: Proračunska bilanca; domaći krediti privatnom sektoru; VECM model; ko-integracija, uzročnost.

JEL: E44; O16; C320 